\title{
Borderless Ideas - Open Innovation in the Hungarian Food Chain ${ }^{1}$
}

\footnotetext{
${ }^{1}$ The authors acknowledge the financial support of the Hungarian Scientific Research Fund (OTKA, K 84327) 'Integration of small farms into the modern food chain', and of the Hungarian Scientific Research Fund (OTKA, PD 116226) 'Supply chain and network performance and relationships in the agribusiness sector'
} 


\begin{abstract}
This paper investigates the innovation performance in the Hungarian food chain using the concept of open innovation. Empirical analysis is based on the data from a 2014 survey of more than 300 small- and medium sized agricultural producers, food processors and food retailers. We analyse innovation performance taking into account not only the direct impacts of external knowledge inflows and absorptive capacity, but also the indirect effect of external knowledge inflows mediated by the existence of potentially complementary internal resources (absorptive capacity). We determine the impact of open innovation and a company's absorptive capacity on innovation performance employing two stage approaches. First, we apply a semi-non parametric probit model. Second, we run cluster analysis to categorise companies based on their open innovation, absorptive capacity, firm and managerial characteristics. Results imply the openness along the food chain may decrease the introduction time of innovation in all areas of innovation, as well the innovation propensity. The openness towards competitors may decrease the introduction time of innovation with regard to technological innovation, but it may increase with regard to product innovation, as well the innovation propensity. The absorptive capacity decreases the introduction time of technological- product, organizational and market innovation. There is a positive relationship between the use of external knowledge (when its defined as openness with competitors) and own innovation capacity with regard to innovation propensity, but not when it is defined as openness along the food chain. The enterprises of the sample are dividing into two groups: innovative (dominated by processors) and not innovative ones (dominated by producers and retailers). The analysis provides valuable inputs for policy-makers and SMEs along the food chain that wish to build and improve (open) innovation system. Policy makers would need more targeted innovation development programs in order to solve the tight innovation bottlenecks. These programs should target first of all at expanding the absorptive capacities of the food chain's enterprises. We also need further research in order to investigate how much the restricted use of open innovation systems in the Hungarian food enterprises is linked to the cost and benefits of creation such systems.
\end{abstract}

\title{
1. Introduction
}

The former communist countries have to face big difficulties and deficiencies in the course of food production with regard the quantity but especially the quality. The most severe problems have disappeared after 1989, albeit the differences in productivity and technological progress between the Central-European and West-European countries have sustained (Steffen and Stephan, 2008). The difference is especially great in the agriculture and food industry. At the current growth rate of technical progress the convergence between the Central- and Western European countries will be a very slow process (Gorton et. al., 2006). Very often the CentralEuropean countries would need further progress in technology, in creation of new products, in procurement procedures which steps would require further substantial innovation and investment activities (Steffen and Stephan, 2008). Central-European countries in general, and Hungary in particular have both a low level of innovation policies and low adoption rate of innovation (Caiazza, 2015). Notwithstanding that the Central-European countries have got some cost advantages compared to the West-European ones - which are mainly due to some foreign direct investments - they hardly can show up these pros at global level.

Therefor our main concern should concentrate towards the quality and innovation issues, which underpin and determine the sustainable competitiveness on the long run (Capitanio et al., 2010; Grunert et al., 2005). In the recent debates researchers concatenate the regional differences in economic performance with the differences in innovation achievements (Abreu et al., 2008; Hansen and Winther, 2011). Policy decision makers are devoting more and more attention to the question, how can they effectively influence the innovation systems in order to 
moderate the regional differences in economic growth. Within the core of this approach there are the local resources and institutions, which can create appropriate innovative environment where the benefits and profits deriving from knowledge share are also distributed among enterprises and local institutions (Cooke, 2001). This attitude is very closely related to the concept of open innovation, which is based on the fact that enterprises (especially small- and medium sized ones, with little or no R\&D (Audretsch and Caiazza, 2015)) are increasingly use resources outside the boundaries of the firms in order to accelerate innovation (Chesbrough, 2003; 2006; 2012). While there is considerable research dealing with the importance of open innovation in the high-tech industries, the number of research studies in food industry is vanishing (see e.g. Enzing et al., 2011; Lefebvre et al., 2015). Furthermore, most of the empirical studies on open innovation in the food industry have primarily focused on large firms. Empirical evidence about open innovation SMEs in general and in the food industry in particular are still limited (Edwards et al., 2005; Avermaete et al., 2004). At the same time according to Archibugi et. al., (1991) open innovation can especially be interesting for the food enterprises, which (in general circumstances) are more dependent on economic resources outside the industry than the other branches.

The paper investigates the innovation performance in the Hungarian food chain. Food industry plays important role in Hungary with substantial positive trade balance. Innovation is fundamental prerequisite in keeping the international competitiveness of the Hungarian food export. Our research can contribute to better understanding of the innovation performance in the Hungarian food chain, which might be useful both for policy decision makers and practitioners. This analysis concentrates on the characterization of the degree in open innovation at different level of the food chain. Innovation in the food chain involves "the producers of agricultural inputs such as fertilizers and seeds, the producers of agricultural goods such as fruits and vegetables, the producers of the final agri-food goods and the distributors of these products" and each of them plays a unique role in impacting innovation (Caiazza et al., 2014a). The research is based on an empirical survey carried out in 2014 in Hungary covering agricultural producers (producers), food processors (processors) and food retailers (retailers). As such, three levels of the food chain is investigated, and we use food processors (and the food industry) as the entry point for the research, based on the definition of "focal company", or in our case 'focal industry', by Spekman et al. (1998). Given the fact that the food chain can reach different levels of complexity and one can distinguish a direct food chain, which is "a company, a supplier, and a customer involved in the upstream and/or downstream flows of products, services, finances, and/or information", from an extended food chain, which "includes suppliers of the immediate supplier and customers of the immediate customer, all involved in the upstream and/or downstream flows of products, services, finances, and/or information" and finally, from an ultimate food chain "includes all the organizations involved in all the upstream and downstream flows of products, services, finances, and information from the ultimate supplier to the ultimate customer" adapted from the definition of Mentzer et al. (2001). Accordingly, we study the direct food chain with regard to the number of levels studied (i.e. three levels), but the direct food chain is not considered from a company perspective (i.e. a company, a supplier, and a customer), but from an industry perspective (i.e. the food industry, the agricultural sector, and the retail sector). In our sample we have included exclusively SMEs. It allows us to derive broader implications for the members of the SME community, which are important players of the European food industry, given the fact that $99 \%$ of the food firms are SMEs, accounting for more than 50\% of the food industry turnover (FoodDrinkEurope, 2014). In this paper we concentrate the analysis on the factors influencing innovation performance, with special regard to different segment of the innovation activities. 
The paper is organised as follows. The next section briefly reviews the literature of open innovation paradigm. We pay special attention to the relation between open innovation and absorptive capacity of the firms. In addition, we derive hypotheses on the relationships between the effects of openness and absorptive capacity on the innovation performance. The empirical analysis includes two steps. First, we analyse the determining factors of innovation performance with special regard to openness, absorptive capacity, managerial attributes and enterprise characteristics applying a semi nonparametric probit model. Second, we apply cluster analysis in which companies are categorised based on their innovation performance on the different areas of innovation, as well as on the overall level of innovation, and we analyse the distribution of the producers, processors and retailers among the different clusters. Finally, we conclude.

\section{The role of open innovation and absorptive capacity}

The concept of open innovation was introduced by Chesbrough (2003). Open innovation systems are cited more and more frequently as notable special mechanism of organizing innovation and there is a growing number of empirical studies that illustrate the positive link between the use of external relationships and the innovation performance of the firm, regardless of the firm's industry (i.e. high-tech vs. low-tech industries) or size (i.e. large vs. small firms) (e.g. Beckeman et al., 2013; Purcarea et al., 2013; Gronum et al., 2012; Köhler et al., 2012; Zeng et al., 2010; Tödtling et al., 2009; Beckeman and Skjöldebrand, 2007; Knudsen, 2007; Nieto and Santamaría, 2007; Amara and Landry, 2005; Menrad, 2004). The idea of open innovation comes from the observation that "by enlarging your "research organization' you may be able to tap into a much larger pool of ideas and find such ideas faster than if you limit yourself to the traditional, closed innovation model" (Torkkeli et. al., 2009 , p. 178). However, there is a drawback. When sharing knowledge, there is a risk of reducing the potential uniqueness of innovations that are developed. This will lead to increased competitive pressures and limit the possibilities of future profits (Torkkeli et al., 2009). Therefore, open innovation is no guarantee for success and several authors have studied the conditions under which participating in an open innovation system is more likely to lead to success than failure (Lichtenthaler, 2011; Reed et al., 2012; Huizingh 2011; Rese and Baier, 2011).

Past studies have for example emphasized the crucial role of a firm's absorptive capacity (Cohen and Levinthal; 1990 Zahra and George, 2002; Escribano et al., 2009; Lane et al., 2001; Tsai, 2001) and the existence of complementary assets (Teece, 1986; Teece et al., 1997) as crucial prerequisites for the success of open innovation. In an open innovation system - in its purest form - all information resources are shared among all participants (Baldwin and von Hippel, 2011). In other words, exclusive information has been disclosed. In such an environment, differences in innovation performance between firms crucially depend on a firm's capacity to acquire and integrate and/or combine the available information (Ambrosini and Bowman, 2009; Eisenhardt and Martin, 2000). Complementary assets - such as proprietary R\&D knowledge, distribution or service networks and manufacturing capabilities - can be decisive in providing such an edge over competitors (Dhanaraj and Parkhe, 2006; Batterink et al., 2010). Absorptive capacity, which is based on the more intense application of intangible assets, makes the firms able to choose information sources vital for their future functioning. Indicators of absorptive capacity relate e.g. to access of skills and external networks (e.g. Escribano et al., 2009; Lane et al., 2001; Tsai, 2001). The benefits of openness are therefore crucially dependent on the existence of complementary resources and absorptive capacity (Pittaway et al., 2004; Dhanaraj and Parkhe, 2006; Batterink et al., 2010; Bessant et al., 2012; van der Borgh et al., 2012; Huggins, 2000; Ozman, 2009; Ireland et al., 2002; Hitt et al., 2000; Hurmelinna-Laukkanen et al. (2012). While we have explained the difference 
between both concepts in the previous paragraph, the literature - especially empirical studies - often uses both terms interchangeably. The reason for this may be related to the difficulty in finding independent proxies for the two concepts. For reasons of simplicity, in the remainder of this paper we will use absorptive capacity to indicate a combination of a firm's tangible and intangible resources that define 'the ability of a firm to acknowledge the value of new external information, to assimilate it and apply it to its activities' (Cohen and Levinthal, 1990). As such, it could be thought of as encompassing the concept of complementary resources. Concluding, we investigate external information flows' (open innovation) impact as well as internal resources' and capabilities' (absorptive capacity) impact on (innovation) performance, as suggested by Caiazza et al. (2015).

Several authors have investigated the complementarity between absorptive capacity and the effective management of external knowledge flows in open innovation systems (Barge-Gil, 2010; Escribano et al., 2009). The resource-based view of the firm supports this thesis and suggests that the benefits from combining new and existing knowledge are more likely to occur when based on complementarity rather than similarity (Teece, 1986; Harrisson et al., 2001). Following work by Kostopoulos et al. (2011) we will therefore analyse innovation performance taking into account not only the direct impacts of external knowledge inflows and absorptive capacity, but also the indirect effect of external knowledge inflows mediated by the existence of potentially complementary internal resources (absorptive capacity).

As such we test three separate hypotheses.

\title{
Hypothesis 1:
}

Open innovation - as evidenced by reciprocity in external information flows - has a direct positive effect on innovation performance

\section{Hypothesis 2:}

\section{Absorptive capacity - i.e. a firm's own resources and capabilities - has a direct positive effect on innovation performance}

\author{
Hypothesis 3: \\ Open innovation has an indirect effect on innovation performance through its interaction \\ with a firm's absorptive capacity. This effect is expected to be positive, to the extent that \\ external knowledge inflows are complementary to internal resources.
}

The following theoretical gaps set the frame of this paper. The focus on external (other players in the food chain and/or competitors) (Hypothesis 1) and internal (company itself) (Hypothesis 2) determinants' impact on the four types of innovation and on the complementary between the external and internal determinants (Hypothesis 3 ) bring us to the field of studies that show that different types of innovations are associated with different types of partners. An overview of these studies is made by Lefebvre (2014) and is presented in Table 1. Such papers are still scarce, especially with regard to non-technological innovations (e.g. market and organizational innovations). As such, this paper aims at contributing to the emerging theory of chain and network management. 
Table 1.

Overview of studies studying the relationship between different types of partners and the four types of innovation

\begin{tabular}{|c|c|c|c|}
\hline Authors & Methodology & $\begin{array}{l}\text { Focus } \\
\text { - types of innovations }\end{array}$ & Main findings \\
\hline (Gemünden et al., 1996) & $\begin{array}{l}\text { Survey; high-tech firms } \\
\text { (biotechnology, EDP, medical } \\
\text { equipment microelectronics and } \\
\text { sensor technology) }\end{array}$ & $\begin{array}{l}\text { Product (new \& } \\
\text { improvements) } \\
\text { Process }\end{array}$ & $\begin{array}{l}\text { Product improvements }(+) \text { related to suppliers \& } \\
\text { customers } \\
\text { New products }(+) \text { related to universities } \\
\text { Process }(+) \text { related to universities \& consultants }\end{array}$ \\
\hline $\begin{array}{l}\text { (Freel, 2003); (Freel and } \\
\text { Harrison, 2006) }\end{array}$ & Survey; manufacturing SMEs & $\begin{array}{l}\text { Product (new to industry) } \\
\text { Process (new to industry) }\end{array}$ & $\begin{array}{l}\text { Product }(+) \text { related to customers \& public (and quasi- } \\
\text { public) sector agencies } \\
\text { Process }(+) \text { related to suppliers \& universities }\end{array}$ \\
\hline $\begin{array}{l}\text { (Amara and Landry, } \\
\text { 2005) }\end{array}$ & Survey; manufacturing firms & $\begin{array}{l}\text { Product \& process (world } \\
\text { first or not) }\end{array}$ & $\begin{array}{l}\text { World first innovation (+) related to research sources (i.e. } \\
\text { universities \& research laboratories) \& (-) related to } \\
\text { market sources (i.e. suppliers, clients, peers, competitors } \\
\& \text { consultants) }\end{array}$ \\
\hline $\begin{array}{l}\text { (Nieto and Santamaría, } \\
\text { 2007) }\end{array}$ & Survey; manufacturing firms & $\begin{array}{l}\text { Product (degree of } \\
\text { novelty) }\end{array}$ & $\begin{array}{l}\text { Degree of product novelty (+) related to suppliers, clients } \\
\text { and research organizations, and (-) related to competitors }\end{array}$ \\
\hline (Tödtling et al., 2009) & $\begin{array}{l}\text { Survey; manufacturing and } \\
\text { service firms }\end{array}$ & $\begin{array}{l}\text { Product (radical \& } \\
\text { incremental) }\end{array}$ & $\begin{array}{l}\text { Radical products }(+) \text { related to with universities and } \\
\text { research organizations Incremental products }(+) \text { related } \\
\text { to providers of business services Product }(+) \text { related to } \\
\text { buyers and suppliers Process }(+) \text { related to buyers and } \\
\text { suppliers No relation between innovation \& competitors }\end{array}$ \\
\hline $\begin{array}{l}\text { (Tomlinson and Fai, } \\
\text { 2013) }\end{array}$ & $\begin{array}{l}\text { Survey; manufacturing SMEs } \\
\text { (aero- space, ceramics, } \\
\text { information technology and } \\
\text { software, textiles and healthcare) }\end{array}$ & $\begin{array}{l}\text { Product } \\
\text { Process }\end{array}$ & $\begin{array}{l}\text { Product }(+) \text { related to buyers and suppliers Process }(+) \\
\text { related to buyers and suppliers No relation between } \\
\text { innovation \& competitors }\end{array}$ \\
\hline
\end{tabular}


The next section will present empirical evidence on the innovation performance in the Hungarian food chain. Because only SMEs have been included, the dataset is likely to underrepresent total innovation efforts in the Hungarian food industry (especially in-house innovation is likely to occur more frequently in large enterprises). However, focusing on SMEs is interesting when investigating the openness with regard to innovation. Several authors claim that openness creates unique benefits for small firms. Because they have limited access to internal resources to dedicate to innovation, they have a greater need to be open to external sources of knowledge. Furthermore, small firms are more vulnerable to internal innovation project failures as these could compromise the viability of the whole firm. Finally, some authors also suggest that small firms are in a better position than large firms to reap the benefits of open innovation because they are more flexible and can respond more quickly to opportunities. Open innovation may therefore be more important in the context of SMEs (Barge-Gil, 2010; Bayona et al., 2001; Nieto and Santamaria, 2010; Rothwell and Dodgson, 1994; Tether, 2002). On top of these, there are challenges that may be particular for SMEs relating to openness with regard to innovation, which justify our interest in focusing on SMEs. For instance, as compared to large firms, SMEs do not have the resources and practices that are needed to develop and manage reciprocal information flows with wide and diverse networks of partners (Columbo et al., 2012; Hausman, 2005). Further, because of their specialized knowledge base linked to their core business, they often face difficulties when they need to exploit new information in areas out of their core business (Bianchi et al., 2010; Huggins and Johnston, 2009). Also, they often cannot reflect on their business strategically, which makes them at the mercy of others (Vos, 2005) and prevents them to clearly define their need for external information (Klerkx and Leeuwis, 2008). Finally, besides the above benefits and challenges, the question of win-or-lose, and especially who wins or who loses in open innovation in the context of SMEs further motivate our interest in focusing on SMEs. The win-or-lose principle is a simple guide for open innovation in general, and in the context of SMEs in particular to reaching an agreement that is beneficial for all partners (Slowinski and Sagal, 2010). With regard to this, a difference can be made between open innovation with buyers and suppliers along the food chain, and with competitors in networks. Concerning open innovation between buyers and suppliers along the food chain, the focus on how all partners can achieve their objective (or win) (with a focus on mutual interest like to serve customers better than competitors for instance) acceptable compromises can be reached and a fair outcome can be achieved (Slowinski and Sagal, 2010). Concerning open innovation between competitors in networks, Pittaway et al. (2004) find that the main benefits include risk sharing, accessing to new markets, technologies and knowledge, pooling complementary skills, speeding products to market and safeguarding property rights. However, in order to reach these benefits, the importance of planning, control, trust and coordination is also underpinned. Gardet and Fraiha (2012) shows that for assuring these benefits, the focal company changes the tools it uses for coordinating (i.e. communication, trust, division of benefits, guarantees of cooperation and conflict resolution) in function of its dependence towards the other partners and the collaborative phase they are in. Rampersad et al. (2010) find that harmony, defined as the development of mutual interests among partners, is positively influenced by trust, control, and coordination. Harmony, in turn, positively impacts network efficiency, which leads to network effectiveness. In conclusion, when taking a decision to participate in open innovation between competitors in networks, firms weight the benefits against the risks, as such, the success of such networks lies in the creation of an environment that can play the dual function of increasing the benefits and reducing the risks (Lefebvre, 2014). For food SMEs with high level of product or process innovations, the danger is high that their firm-specific inputs (i.e. product or process innovations) will be 
exploited by other firms when disclosed. As such, food SMEs with high level of product or process innovations choose networks where information is confidentially shared in order to protect firm-specific inputs on which they build their competitive advantage. Quite the reverse, food SMEs with high level of market innovations, these concerns are lower as market innovations are meant to be disclosed and are probably built on tacit knowledge, known to be less imitable (Nonaka et al., 2000). These firms can thus choose networks that can provide them with larger amount of new knowledge, that is networks where information is openly shared among network partners.

\section{Methodology}

\subsection{The sample and key variables}

To investigate SMEs' open innovation and to test the determinants of innovation performance, a questionnaire was designed and data were collected in Hungary in 2014. The sample covers three stages of the food chain; producers, processors and retailers. The survey includes information on "Knowledge accumulation and use in the food industry" as well as on "Cooperation and clustering as the keys of intense and effective business". In addition to the main data and activities of the enterprises we have collected data on cooperation- and clustering, knowledge-, research- and innovation management and some financial information. The sample was drawn on the Central Statistical Office' database and the surveyed 302 firms include 100 producers, 101 processors and 101 retailers. The SME is defined as a firm with less than 250 employees (CIAA, 2009).

Innovation is defined as the successful exploitation of new ideas into either new 'processes', 'products, 'ways of organizing' and 'markets' (Pittaway et al., 2004; Lundvall, 1995). Process innovation is the main orientation of food firms (Archibugi et. al. 1991) using new technologies leading to for instance a reduction of the processing time or an improvement in operating conditions (Cárcel et al., 2012). Product innovation relates to for instance improving nutritional properties by reducing the content of the unhealthy substances and promoting the presence of other substances with healthy benefits (e.g. salt reduction, functional ingredients) (Toldrá et al., 2011). Organizational innovation refers to for instance changes in marketing, purchases, sales, administration, management and staff policy (Bigliardi and Dormio, 2009). Market innovations links to for instance the exploitation of new territorial markets and the penetration of new market segment within existing markets (Bigliardi and Dormio, 2009). Accordingly, the innovation performance was measured on these different areas of innovation (technological (or process), product, organizational, market) (Caiazza et al., 2014a; Pittaway et al., 2004; Lundvall, 1995), because the different areas of innovation can impact different level of the food chain and may vary depending on the relative power of players (Caiazza et al., 2014b). Therefore, we used the following questions: "When did you start to use this technology in your major activity?", "When did you start to produce this product?", "When did you change your organisational structure last time?", "When did you change your marketing (input- and output) channels last time?", with the following options to choose from: within a year, in one-two year, in two-three years, in three-four years, in more than five years" ${ }^{2}$. By using principal factor analysis of the four variables of innovation performance, we developed a composite measure of innovation propensity. Both Bartlett test ( $p$ value: 0.000) and Kaiser-Meyer-Olkin Measure (0.755) show that our data is appropriate for factor analysis.

\footnotetext{
${ }^{2}$ The innovation variables take the following values: within one year: within a year $=5,1-2$ years $=4,2-3$ year $=3$, 3-4 years $=2$, more than 5 years $=1$.
} 
After varimax rotation eigenvalue and Akaike information criteria clearly identify one factor solution that is we can create one composite indicator from four innovation variables. ${ }^{3}$

Different indicators have been used in the literature to measure openness with regard to innovation (open innovation) and absorptive capacity. For the openness with regard to innovation we used two indicators. The first is the level of reciprocity in external knowledge transfer throughout the food chain, based on Tomlinson and Fai (2013) studying product and process innovation related to buyers and suppliers. The second is the level of reciprocity in external knowledge transfer between competitors based on Amara and Landry (2005) studying product and process innovation, Nieto and Santamaría (2007) studying product innovation and Tomlinson and Fai (2013) studying product and process innovation related to competitors. The following questions were used: "Is there reciprocity in knowledge sharing in the supplier-buyer chain?“ and „Is there reciprocity in knowledge sharing with your competitors?" with the option to choose from a five-point response scale ranging from not at all (1) to completely (5)". For the absorptive capacity we used the company's own R\&D expenditures compared to the total turnover (this is in line with empirical studies by Belderbos et al., (2004), Cassiman and Veugelers (2002), Oltra and Flor (2003) and Stock et al. (2001)) with the options to choose from (0) $0 \%$, (1) $1-2 \%$, (2) $3-5 \%$, (3) $>5 \%$.

Apart from our emphasis on the role of the openness with regard to innovation and a company's absorptive capacity, we derive a number of additional determinants from the literature (Avermaete et al., 2004; Abdelmoula and Etienne, 2010). Therefor we also have included the manager attributes, i.e. managerial experience in years, with the options to choose from (1) < 5 years, (2) 6-10 years, (3) 11-15 years, (4) 16-20 years, (5) > 26 years, the level of the food chain which the firm is belonging to, with the options to choose from (1) producer, (2) processor, (3) retailer. On top of these, internal and external specificities of the enterprise were also recorded. Firm's size measured with total turnover of the enterprise in 2013 in million HUF, with the options to choose from (1) 1-5, (2) 5-10, (3) 10-50, (4) 50-200, (5) $200-500$, (6) 500-1000, (7) > 1000, firm's age with the options to choose from $(1)<5$ years, (2) 6-10 years, (3) 11-15 years, (4) 16-20 years, (5) > 26 years, and ratio of qualified employees measured with the $\%$ of employees speaking at least one foreign language, with the options to choose from (0) $0 \%$, (1) $1-10 \%$, (2) $10-30 \%$, (3) > $30 \%$ were listed under internal characteristics of enterprise. Export connection, measured with the question if the enterprise directly sell abroad and foreign ownership, measured with the question if the foreign ownership is $>0 \%$ were used as external attributes of the enterprise. Appendix 1 gives an overview of variables affecting the innovation performance.

\subsection{Analyses}

Analyses are done in two steps. First, we used semi nonparametric ordered probit model by econometric analysis. Because the answers on innovation are based on 1-5 Lickert scale, we can estimate various discrete choice models in order to test our hypotheses. However, semi parametric literature emphasise that parametric estimators of discrete choice models are known to be sensitive to departure from distributional assumptions. Various estimators have been developed for correcting this restrictive nature of parametric models (Stewart, 2004). In this paper we apply the semi-nonparametric approach of Gallant and Nychka (1987). Table 4 shows the results of the semi-nonparametric ordered probit models.

Second, we calculated estimations by cluster analysis. We employed cluster analysis with kmedians. The Calinski-Harabasz pszeudo-F index identifies two clusters. Table 5 includes the means of the two clusters, while Figure 1 shows the individual clusters along the food chain segments

\footnotetext{
${ }^{3}$ The greater the number the higher the innovation propensity, the lower the number the slower the innovation propensity.
} 
However, before these analyses, we investigated the descriptive statistics of the variables both for the whole sample (Table 2) and for the levels of the food chain (Table 3).

\section{Results}

The existence of most recent innovations is not very common in the sample. Average values of different areas of innovation are more than 2,50, except for organizational innovation (Table 2). The highest values refer to product and market innovation. It suggests that these companies produce the same product about 2-3 years, and they also use the same marketing channels 2-3 years. We can observe the lowest value with regard the organizational innovation; and a somewhat higher, but still quite low value with regard the technological innovation.

\section{Table 2.}

\section{Descriptive statistics of variables}

\begin{tabular}{llllll}
\hline & N & mean & st. dev. & min & max \\
\hline Innovation areas & & & & & \\
\hline Technological innovation & 302 & 2.77 & 1.28 & 1 & 5 \\
& 302 & 3.45 & 1.74 & 1 & 5 \\
Product innovation & 302 & 2.30 & 1.10 & 1 & 5 \\
Organizational innovation & 302 & 3.31 & 1.68 & 1 & 5 \\
& 302 & 0.00 & 0.85 & -1.23 & 1.01 \\
Market innovation & & & & & \\
Innovation propensity & 302 & 2.47 & 1.46 & 1 & 5 \\
\hline Open innovation and absorptive capacity & & & & & \\
\hline & 302 & 1.86 & 0.94 & 1 & 5 \\
Openness food chain & 302 & 1.12 & 1.29 & 0 & 3 \\
Openness competitors & & & & & \\
Absorptive capacity & 298 & 3.15 & 1.50 & 1 & 6 \\
\hline Manager attributes & & & & & \\
\hline Managerial experience & 290 & 5.75 & 1.41 & 1 & 7 \\
\hline Internal characteristics of the enterprise & 292 & 3.82 & 1.49 & 1 & 6 \\
\hline Firm's size & 302 & 1.68 & 1.01 & 0 & 3 \\
Firm's age & & & & & \\
Ratio of qualified employees & 291 & 1.79 & 0.41 & 1 & 2 \\
\hline External attributes of the enterprise & 302 & 0.05 & 0.22 & 0 & 1 \\
\hline Export connections & & & & \\
Foreign ownership & & & & & \\
\hline
\end{tabular}

Source: Own estimation based on survey

Questions relating to open innovation show that knowledge sharing within the food chain are higher than among the firm and competitors. The average value of absorptive capacity is very low which is shown by the less than 3\% ratio (around 1-2 \%) of the R\&D expenditures compared to the total turnover. The average managerial experience is around 15 years. The average sized firm has got around 500-1000 million HUF (roughly 1,6 - 3,2 million EUR) turnover a year, and is around 15-20 year old. Around 10-30\% of employees speak at least one foreign language, and as an average, $30 \%$ of the SMEs sell directly abroad. This is rather low, compared e.g. to the empirical research of Caiazza et al. (2016) and Caiazza and Volpe 
(2014c) in the Italian food chain, where the analyzed companies export $60 \%$ of their products on average, and where open innovation found to enable companies to compete abroad. However, given that export connections are only used as determinants of innovation performance, this is not analysed more in depth, only to the extent to which export connections enable or draw back innovation performance. Almost none of the companies have foreign ownership.

Table 3.

Means of variables along the food chain

\begin{tabular}{|c|c|c|c|c|}
\hline & Producer & Processor & Retailer & K-W \\
\hline \multicolumn{5}{|l|}{ Innovation areas } \\
\hline Technological innovation & 2.9 & 3.20 & 2.21 & 0.00 \\
\hline Product innovation & 2.51 & 4.62 & 3.21 & 0.00 \\
\hline Organizational innovation & 1.88 & 2.85 & 2.15 & 0.00 \\
\hline Market innovation & 2.37 & 4.49 & 3.05 & 0.00 \\
\hline Innovation propensity & -0.52 & 0.61 & -0.09 & 0.00 \\
\hline \multicolumn{5}{|c|}{ Open innovation and absorptive capacity } \\
\hline Openness food chain & 1.52 & 3.66 & 2.25 & 0.00 \\
\hline Openness competitors & 1.42 & 2.61 & 1.61 & 0.00 \\
\hline Absorptive capacity & 0.68 & 1.76 & 1.00 & 0.00 \\
\hline \multicolumn{5}{|l|}{ Manager attributes } \\
\hline Managerial experience & 3.16 & 3.44 & 2.79 & 0.02 \\
\hline \multicolumn{5}{|c|}{ Internal characteristics of the enterprise } \\
\hline Firm's size & 5.49 & 5.92 & 5.74 & 0.82 \\
\hline Firm's age & 4.78 & 3.94 & 2.78 & 0.00 \\
\hline Ratio of qualified employees & 0.86 & 1.80 & 2.48 & 0.00 \\
\hline \multicolumn{5}{|c|}{ External attributes of the enterprise } \\
\hline Export connections & 1.97 & 1.74 & 1.64 & 0.00 \\
\hline Foreign ownership & 0.01 & 0.04 & 0.09 & 0.01 \\
\hline
\end{tabular}

Source: Own estimation based on survey

Note: K-W: Kruskal-Wallis test p value

Average values of different areas of innovation are the highest at processors and the lowest at producers (expect for technological innovation, which is the highest at processors and the lowest at retailers). With regard to the different areas of innovation at the different levels of the food chain, the highest values refer to product and market innovation and the lowest value refers to organizational innovation at all levels of the food chain. Openness towards other players in the food chain as well as towards competitors is the largest at processors and the lowest at producers. The same is true for absorptive capacity (Table 3 ).

When it comes to internal and external characteristics, producers are the smallest, their companies are the oldest, and the ration of qualified employees are the lowest, which is a typical example of companies at the producer segment of the food chain. The processors' managers have the most experience in terms of years, as compared to the other two groups, 
and they are the biggest, in terms of annual turnover. The employees of the retailers are the most qualified, and their companies are the youngest.

\subsection{Factors determining innovation performance}

Table 4 shows the results of the semi-nonparametric ordered probit models. Our outcomes imply that the factors determining the innovation performance may be dissimilar in different areas of innovation.

\section{Hypothesis 1: partly accepted \\ Open innovation - as evidenced by reciprocity in external information flows - has a direct positive effect on innovation performance}

The openness along the food chain may decrease the introduction time of innovation in all areas of innovation, as well the innovation propensity. The openness towards competitors affects the introduction time of innovation differently, namely it may decrease the introduction time of innovation with regard to technological innovation, but it may increase with regard to product innovation, as well the innovation propensity. As such, our first hypothesis is accepted for open innovation along the food chain for the different areas of innovation, as well as for innovation propensity. However, although our first hypothesis is accepted for open innovation with competitors for technological innovation, but rejected for product innovation and for innovation propensity.

\section{Hypothesis 2: accepted \\ Absorptive capacity - i.e. a firm's own resources and capabilities - has a direct positive effect on innovation performance}

The absorptive capacity decreases the introduction time of technological- product, organizational and market innovation, accepting our second hypothesis.

\section{Hypothesis 3: partly accepted}

Open innovation has an indirect effect on innovation performance through its interaction with a firm's absorptive capacity. This effect is expected to be positive, to the extent that external knowledge inflows are complementary to internal resources.

There seems to be a negative relationship between the use of external knowledge (openness along the food chain) and own innovation capacity (absorptive capacity) in creating all type of innovation, as well as with regard to innovation propensity. However, there is a positive relationship between the use of external knowledge (when its defined as openness with competitors) and own innovation capacity with regard to innovation propensity. Openness along the food chain and absorptive capacity seem to be substitutes rather than complements in the Hungarian food industry. However, openness with competitors complements absorptive capacity in creating innovation. As such, our third hypothesis is partly rejected and open innovation along the food chain doesn't have an indirect effect on innovation performance through its interaction with the firm's absorptive capacity, but it is partly accepted because of the results indicating indirect effect of open innovation with competitors through its interaction with the firm's absorptive capacity. More generally speaking this would lead to a conclusion that on one hand, the innovation model is more closed with regard to other players in the food chain (depending on own resources rather than on others'), on the other hand, it is more open with regard to competitors. 
The firm specific variables show more or less consistent results, however, there are some interesting points to be discussed. The effect of firm's size (total turnover) stimulates companies in introducing technological innovation faster. The effect of qualification of employees (speaking foreign languages) is a drawback for the introduction time of technological innovation, but is a stimulus for the introduction time of product innovation. Further, generally speaking, on innovation propensity the effect is positive. The older the firm the faster the introduction of product innovation, but the slower the introduction of organizational innovation, and it seems that with the increasing experience the innovation propensity increase. The export connections rather draw back the faster organizational innovation. At the end processors have got bigger chance of being more innovative in the fields of technology, product and organisation as well as innovation propensity than retailers. The producers' advantage appears in higher technological- and product innovation compared to the retailers. These results are in line with suggestions of Caiazza and Volpe (2012) namely that "variety in level of education", "technology used", "productivity", "level of organization", firm's size along the food chain is reflected in the "sort of relationship" between players and the type of food chain they create.

Table 4.

The results of the semi-nonparametric ordered probit model

\begin{tabular}{|c|c|c|c|c|c|}
\hline & Technological & Product & Organisational & Market & $\begin{array}{l}\text { Innovation } \\
\text { propensity }\end{array}$ \\
\hline Openness food chain & $0.711 * * *$ & $0.626 * * *$ & $0.447 * * *$ & $1.089 * * *$ & $0.326 * * *$ \\
\hline Openness competitors & $0.374 * *$ & $-0.169 *$ & -0.071 & -0.187 & $-0.154^{*}$ \\
\hline Absorptive capacity & $0.905 * * *$ & $0.374 *$ & $0.534 * * *$ & $1.053 * * *$ & 0.118 \\
\hline $\begin{array}{l}\text { Openness food chain* } \\
\text { Absoprtive capacity }\end{array}$ & $-0.152 *$ & $-0.175 * * *$ & $-0.170 * * *$ & $-0.283 * * *$ & $-0.070 * *$ \\
\hline $\begin{array}{l}\text { Openness competitors * } \\
\text { Absoprtive capacity }\end{array}$ & -0.169 & 0.066 & -0.001 & 0.034 & $0.082 * *$ \\
\hline Managerial experience & 0.017 & -0.008 & -0.024 & 0.037 & 0.013 \\
\hline Firm's size & $0.114 * *$ & 0.033 & 0.005 & 0.016 & 0.022 \\
\hline Ratio of qualified employees & $-0.193 * *$ & $0.207 * * *$ & 0.067 & 0.127 & $0.211 * * *$ \\
\hline Firm's age & -0.113 & $0.133 *$ & $-0.119 * *$ & 0.067 & $0.065 *$ \\
\hline Export connections & -0.031 & -0.141 & $-0.219 *$ & 0.014 & -0.083 \\
\hline Foreign ownership & 0.061 & -0.149 & -0.232 & -0.241 & -0.145 \\
\hline Producers & $1.136 * * *$ & $0.484 * *$ & 0.210 & 0.177 & -0.096 \\
\hline Processors & $0.965 * *$ & $0.616 * *$ & $0.381 *$ & 0.467 & $0.297 * *$ \\
\hline Constant & & & & & $-1.267 * * *$ \\
\hline $\mathrm{N}$ & 275 & 275 & 275 & 275 & 275 \\
\hline
\end{tabular}

Source: Own estimation based on survey

Note: Significance levels *** $1 \%$; * $5 \%$; $10 \%$

\subsection{Clusters}

Table 5 includes the means of the two clusters, while Figure 1 shows the individual clusters along the food chain segments. The first cluster is the smaller one as far as the number of firms is concerned $(\mathrm{N}=80)$. It can be characterized as having higher scores for all areas of innovation, as well as for innovation propensity; as such they are called the innovative cluster. Within this cluster, the number one innovation is market innovation, while the number two is product innovation. The second cluster consists of 195 firms, where the enterprises are less innovative (not innovative cluster). Organization innovation is the least applied, followed by 
technological innovation, market innovation, and at the end, product innovation. The two clusters are significantly different for all areas and for innovation propensity, except for technological innovation.

Table 5.

The results of cluster analysis

\begin{tabular}{llll}
\hline & Innovative & Not innovative & K-W \\
\hline Innovation areas & & & \\
Technological innovation & 2.99 & 2.78 & 0.29 \\
Product innovation & 4.38 & 3.19 & 0.00 \\
Organizational innovation & 2.60 & 2.24 & 0.00 \\
Market innovation & 4.46 & 2.97 & 0.00 \\
Innovation propensity & 0.57 & -0.17 & 0.00 \\
\hline $\mathrm{N}$ & 80 & 195 & \\
\hline
\end{tabular}

Source: Own estimation based on survey

Note: K-W: Kruskal-Wallis test p value

The distribution of segments (levels of food chain) within the three clusters is considerable different from each other (Figure 1). The innovative cluster is dominated by processors, while the not innovative cluster by producers and retailers.

Figure 1.

Number of firms across clusters

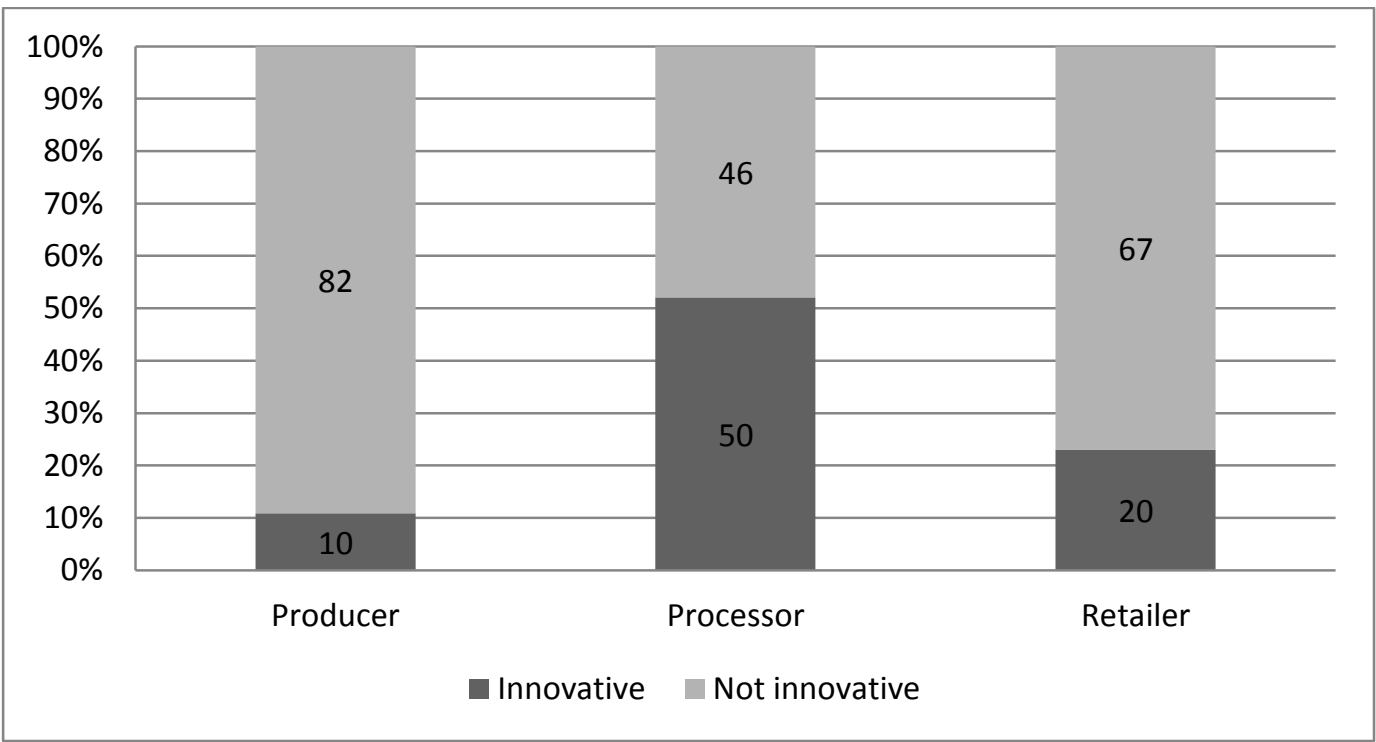

Source: Own estimation based on survey

\section{Discussion and summary}

Innovation performance is identified as key factor of competitiveness (Capitanio et al., 2010; Grunert et al., 2005). Innovation is even more relevant in the context of the Hungarian food chain, a sector that has traditionally been internationally oriented but that also suffers from the legacy of former communist rule in which quality and innovative content of products and services was not a priority. The paper has looked specifically at the role of openness with regard to innovation and a firm's absorptive capacity for explaining innovative performance. 
We find that open innovation is seen as natural practice of the agri-food SMEs because of two reasons: $(a)$ from technological point of view the whole food chain behaves like a mature industry where break-through type of innovation is very rare and incremental innovations occur in intense consultation with buyers, suppliers and other business partners- and institutions, and $(b)$ the SMEs do not have enough financial-, labour- and infrastructural capacity to carry out own conventional closed type (R\&D) of innovation.

We investigated four areas of innovation: technological-, product-, organizational- and market innovation. Estimations reveal that there are differences between innovation areas. Productand market innovation move very close to each other, which is a good indication of the validity of our analysis. Organizational innovation lags behind the technological one, what also proves that organizational changes are usually following the introduction of new technologies.

Results highlight significant differences between the three levels of the food chain with respect to their innovation activities. All four types of innovation and general innovation propensity are the fastest at processors. However, when looking at the different areas of innovation at the different levels of the food chain, our result suggest that regardless of the significant differences between the three levels of the food chain with respect to innovation activities, the three levels of the food chain value the different areas of innovation the same way (they value the most product and market innovation). Similarly, openness and absorptive capacity is also the highest at processors, and the lowest at producers.

Semi-nonparametric ordered probit model results imply the openness along the food chain may decrease the introduction time of innovation in all areas of innovation, as well the innovation propensity. The openness towards competitors may decrease the introduction time of innovation with regard to technological innovation, but it may increase with regard to product innovation, as well the innovation propensity. The absorptive capacity decreases the introduction time of technological- product, organizational and market innovation. There is a positive relationship between the use of external knowledge (when its defined as openness with competitors) and own innovation capacity with regard to innovation propensity, but not when it is defined as openness along the food chain. Processors have got bigger chance of being more innovative in the fields of technology, product and organisation as well as innovation propensity than retailers. The producers' advantage appears in higher technological- and product innovation compared to the retailers.

The results of cluster analysis indicate that the enterprises of the sample are dividing into two groups: innovative (dominated by processors) and not innovative ones (dominated by producers and retailers).

These results contribute to filling the gap in the emerging theory of chain and network management with regard to the relationship between different types of innovations (also nontechnological innovations, like market and organizational innovation) and the different types of partners.

The empirical results reveal that there exist ambiguous assessment of open innovation and it doesn't necessarily promote the innovation performance. Consequently our first hypothesis (Open innovation - as evidenced by reciprocity in external information flows - has a direct positive effect on innovation performance) is only partly accepted. This proposition is valid in 
case of open innovation along the food chain for all types of innovation and for innovation propensity, as well as in case of open innovation with competitors for technological innovation, but not for product innovation or innovation propensity. Our second hypothesis (Absorptive capacity - i.e. a firm's own resources and capabilities - has a direct positive effect on innovation performance) seems to be more generalized: the absorptive capacity stimulates introducing innovative solutions in all areas, accepting our second hypothesis. Our third hypothesis (Open innovation has an indirect effect on innovation performance through its interaction with a firm's absorptive capacity. This effect is expected to be positive, to the extent that external knowledge inflows are complementary to internal resources) is partly rejected because open innovation along the food chain doesn't have an indirect effect on innovation performance through its interaction with the firm's absorptive capacity, but it is partly accepted because of the results indicating indirect effect of open innovation with competitors through its interaction with the firm's absorptive capacity.

The analysis provides valuable inputs for policy-makers and SMEs along the food chain that wish to build and improve (open) innovation system. Policy makers would need more targeted innovation development programs in order to solve the tight innovation bottlenecks. These programs should target first of all at expanding the absorptive capacities of the food chain's enterprises. For instance, they "can realize some information programs that aim to reduce the information search costs associated with" an innovation and "exchange programs to improve adopters' absorptive capability or reinforce their existing personnel propensity to use" an innovation. However, besides absorptive capacities (i.e. a demand-side barrier), the other bottlenecks (i.e. general and supply-side barriers) should also simultaneously be addressed avoiding a too narrow scope leading to poor results (Caiazza, 2015). We also need further research in order to investigate how much the restricted use of open innovation systems in the Hungarian food enterprises is linked to the cost and benefits of creation such systems.

One of the most prominent findings of this article is that openness along the food chain and with competitors cannot be considered as being the same. Openness with competitors doesn't promote product innovation or innovation propensity. As such, food SMEs should engage and access to strategic resources in inter-organizational initiatives differently with regard to their buyers and suppliers and with regard to their competitors, especially for product innovation. Policy makers and other stakeholders that support the creation and maintenance of open innovation systems are therefore recommended to pay particular attention to this when designing such systems.

With regard to absorptive capacity, the results clearly indicate a positive impact on all types of innovation. As such, if food SMEs and policy makers fails to understand the importance of increasing internal $R \& D$ expenditures of food SMEs, this may seriously jeopardize the success of their innovation efforts.

Further, given the fact that openness along the food chain and absorptive capacity seem to be substitutes rather than complements, open innovation along the food chain seems not to be the solution for having low internal R\&D expenditures of food SMEs in creating innovative solutions. However, since openness with competitors complements absorptive capacity, once the above mentioned burdens of openess with competitors are managed, and internal R\&D is given, the two in combination could increase innovation performance.

Some limitations of the paper are worth mentioning. The study is limited in its scope with regard to the research setting and the unit of analysis (Hungarian food chain). With regard to the former, our sample consists of 302 SMEs along the food chain, almost equally distributed as producers, processors and retailers. At the end of 2014 in Hungary there were 7766 
producers, 2681 processors and 6420 retailers in this category, which means 1,3-3,7\% coverage (Agrárgazdasági Kutatóintézet, 2014). Regarding the latter, the paper defines food chain in a narrow sense (three levels); therefore, the results represent the perspectives of a limited number of food chain partners (producers, processors, retailers). Were the definition to be widened, input from additional members would be necessary (such as suppliers of suppliers, customers of customers, third parties, or competitors). Nevertheless, although the scope may be narrow, it is appropriate for our objective. Future research is recommended to overcome the paper's limitations (i.e. extend its scope to other countries, sectors and levels of chain).

\section{Appendix}

\section{Appendix 1.}

\section{Description of the explanatory variables}

\begin{tabular}{|c|c|}
\hline \multicolumn{2}{|r|}{ Innovation areas } \\
\hline Technological innovation & When did you start to use this technology in your major activity? \\
\hline Product innovation & When did you start to produce this product? \\
\hline Organizational innovation & When did you change your organisational structure last time? \\
\hline Market innovation & $\begin{array}{l}\text { When did you change your marketing (input- and output) channels } \\
\text { last time? }\end{array}$ \\
\hline Innovation propensity & Composite measure of innovation propensity \\
\hline \multicolumn{2}{|r|}{ Open innovation and absorptive capacity } \\
\hline Openness food chain & $\begin{array}{l}\text { Is there reciprocity in knowledge sharing in the supplier- } \\
\text { buyer chain? }\end{array}$ \\
\hline Openness competitors & $\begin{array}{l}\text { Is there reciprocity in knowledge sharing with your } \\
\text { competitors? }\end{array}$ \\
\hline Absorptive capacity & R\&D/turnover \\
\hline \multicolumn{2}{|r|}{ Food chain segment } \\
\hline Producer & Dummy: 1 if the respondent SME is a producer \\
\hline Processor & Dummy: 1 if the respondent SME is a processor \\
\hline Retailer & Dummy: 1 if the respondent SME is a retailer \\
\hline \multicolumn{2}{|r|}{ Manager attributes } \\
\hline Managerial experience & Managerial experience in years \\
\hline \multicolumn{2}{|r|}{ Internal characteristics of the enterprise } \\
\hline Firm's size & Total turnover of the enterprise in 2013 \\
\hline Firm's age & Age of firm in years \\
\hline Ratio of qualified employees & $\begin{array}{l}\text { How many } \% \text { of employees speak at least one foreign } \\
\text { language? }\end{array}$ \\
\hline \multicolumn{2}{|r|}{ External attributes of the enterprise } \\
\hline Export connections & Dummy: 1 if the enterprise directly sell abroad \\
\hline Foreign ownership & Dummy: 1 if the foreign ownership is $>0 \%$ \\
\hline
\end{tabular}

\section{References}

Abdelmoula, M., Etienne, J.M. (2010). Determination of R\&D investment in French firms: A two-part hierarchical model with correlated random effects, Economics of Innovation and New Technology, 19 (1): 53-70. 
Abreu, M., Grinevich, V., Kitson, M., Savona, M. (2008). Absorptive capacity and regional patterns of innovation. DIUS Background Paper for the Innovation Nation White Paper, London: DIUS.

Agrárgazdasági Kutatóintézet. (2014). Központi Statisztikai Hivatal : Agrárstatisztikai Zsebkönyv - 2014, Budapest, 2015, p. 18, p. 45.; https://www.ksh.hu/docs/hun/xstadat/xstadat_evkozi/e_okk004.html, downloaded: 8 Feb 2016)

Amara, N. \& Landry, R. (2005), "Sources of information as determinants of novelty of innovation in manufacturing firms: Evidence from the 1999 statistics Canada innovation survey", Technovation, 25, 3, 245-259.

Ambrosini, V. \& Bowman, C. (2009), "What are dynamic capabilities and are they a useful construct in strategic management?", International Journal of Management Reviews, 11, 1, 29-49.

Archibugi, D., S. Cesaratto és G. Sirilli (1991). Sources of innovative activities and industrial organization in Italy. Research Policy, 20: 299-313.

Audretsch, D., \& Caiazza, R. (2015). Technology transfer and entrepreneurship: crossnational analysis. The Journal of Technology Transfer, 1-13.

Avermaete, T., Viaene, J., Morgan, E.J., Crawford, N. \& Mahon, D. (2004), "Determinants of product and process innovation in small food manufacturing firms", Trends in Food Science \& Technology, 15, 10, 474-483.

Baldwin, Carliss, and Eric von Hippel (2011). Modeling a paradigm shift: From producer innovation to user and open collaborative innovation. Organization Science 22.6 (2011): 1399-1417.

Barge-Gil, A. (2010). Open, Semi-Open and Closed Innovators: Towards an Explanation of Degree of Openness. Industry and Innovation 17 (6): 577-607.

Battisti, G.; Stoneman, P. (2010). How innovative are UK firms? Evidence from the CIS4 on synergies between technological and organisational innovation. British Journal of Management, 34 (1): 187-206.

Batterink, M.H., Wubben, E.F.M., Klerkx, L. \& Omta, O.S.W.F. (2010), "Orchestrating innovation networks: The case of innovation brokers in the agri-food sector", Entrepreneurship and Regional Development, 22, 1, 47-76.

Bayona, C., Garci'a-Marco, T., Huerta, E. (2001). Firms' motivations for cooperative R\&D: an empirical analysis of Spanish firms", Research Policy 30: 1289-1307.

Beckeman, M., Bourlakis, M. \& Olsson, A. (2013), "The role of manufacturers in food innovations in sweden", British Food Journal, 115, 7, 953-974.

Belderbos, R., Carree, M.A., Diederen, B., Lokshin, B., Veugelers, R. (2004). Heterogeneity in R\&D cooperation strategies. International Journal of Industrial Organization 22 (8-9): 1237-1263.

Bessant, J., Alexander, A., Tsekouras, G., Rush, H. \& Lamming, R. (2012), "Developing innovation capability through learning networks", Journal of Ecocomic Geography, 12, 5, 1087-1112.

Bianchi, M., Cavaliere, A., Chiaroni, D., Frattini, F. \& Chiesa, V. (2011), "Organizational modes for open innovation in the bio-pharmaceutical industry: An exploratory analysis", Technovation, 31, 1, 22-33.

Bigliardi, B., \& Ivo Dormio, A. (2009). An empirical investigation of innovation determinants in food machinery enterprises. European Journal of Innovation Management, 12(2), 223242.

Caiazza, R., \& Volpe, T. (2012). The global agro-food system from past to future. China-USA Business Review, 11(7), 919-929. 
Caiazza, R., Volpe, T., \& Audretsch, D. (2014a). Innovation in agro-food chain: Policies, actors and activities. Journal of Enterprising Communities: People and Places in the Global Economy, 8(3), 180-187.

Caiazza, R., Audretsch, D., Volpe, T., \& Debra Singer, J. (2014b). Policy and institutions facilitating entrepreneurial spin-offs: USA, Asia and Europe. Journal of Entrepreneurship and Public Policy, 3(2), 186-196.

Caiazza, R. O. S. A., \& Volpe, T. I. Z. I. A. N. A. (2014c). Agro-Food Firms' Competitiveness: Made in Italy in the World. International Review of Management and Business Research, 3(2), 1790-1796.

Caiazza, R., Richardson, A., \& Audretsch, D. (2015). Knowledge effects on competitiveness: From firms to regional advantage. The Journal of Technology Transfer, 40(6), 899-909.

Caiazza, R. (2015). A cross-national analysis of policies affecting innovation diffusion. The Journal of Technology Transfer, 1-14.

Caiazza, R., Volpe, T., \& Stanton, J. L. (2016). Global supply chain: The consolidators' role. Operations Research Perspectives, 3, 1-4.

J.A. Cárcel, J.V. García-Pérez, J. Benedito, A. Mulet. (2012). Food process innovation through new technologies: Use of ultrasound, Journal of Food Engineering, Volume 110, Issue 2, May 2012, Pages 200-207, ISSN 0260-8774

Cassiman, B., Veugelers, R. (2002). R\&D Cooperation and spillovers: Some empirical evidence from Belgium. American Economic Review 44 (3): 1169-1184.

Chesbrough H. (2003) Open Innovation: The New Imperative for Creating and Profiting from Technology. Harvard Business School Press: Boston, MA.

Chesbrough, H. (2006). Open innovation: a new paradigm for understanding industrial innovation. In: Chesbrough, H., W. Vanhaverbeke és J. West (szerk.) Open innovation: researching a new paradigm. Oxford University Press, New York, NY, USA, 1-12.

Chesbrough, H. (2012), "Open innovation where we've been and where we're going", Research- Technology Management, July-August, 20-27.

Cohen, W.M., Levinthal, D.A. (1990). Absorptive capacity: A new perspective on learning and innovation. Administrative Science Quarterly 35(1): 128-152.

Columbo, M.G.C., Laursen, K., Magnusson, M. \& Rossi-Lamastra, C. (2012), "Introduction: Small business and networked innovation: Organizational and managerial challenges", Journal of Small Business Management, 50, 2, 181-190.

Cooke, P. (2001). Regional Innováció Systems, Clusters and the Knowledge Economy, Industrial and Corporate Change, 10 (4), 945-974.

Dhanaraj, C. \& Parkhe, A. (2006), "Orchestrating innovation networks", Academy of Management Review, 31, 3, 659-669.

Dries, L. Fertő, I., Gorton, M., Pascucci, S. (2012): Innovation performance in Hungarian Agri-food Supply Chains: An investigation of the Open Innovation paradigm. Paper presented at WICANEM 2012 conference, Wageningen-Ede.

Escribano, A., Fosfuri, A. \& Tribó, J.A. (2009), "Managing external knowledge flows: The moderating role of absorptive capacity", Research Policy, 38, 96-105.

Edwards, T., Delbridge, R. \& Munday, M. (2005), "Understanding innovation in small and medium- sized enterprises: A process manifest", Technovation, 25, 10, 1119-1127.

Eisenhardt, K.M. \& Martin, J.A. (2000), "Dynamic capabilities: What are they?", Strategic Management Journal, 21, 1105-1121.

Enzing, C.M., Pascucci, S., Janszen, F.H.A., Omta, O.S.W.F. (2011). Role of open innovation in the short- and long-term market success of new products: evidence from the Dutch food and beverages industry. Journal on Chain and Network Science: 11(3): 235-250.

Escribano A, Fosfuri, A., Tribó, J.A. (2009). Managing external knowledge flows: the moderating role of absorptive capacity, Research Policy 39: 96-105. 
F. Capitanio, A. Coppola, S. Pascucci. (2010). Product and process innovation in the Italian food industry, Agribusiness: An International Journal, 26 (2010), pp. 503-518

Fidel Toldrá, Milagro Reig. (2011) Innovations for healthier processed meats, Trends in Food Science \& Technology, Volume 22, Issue 9, September 2011, Pages 517-522, ISSN 0924-2244

Fooddrinkeurope, 2014. Data \& trends of the european food and drink industry 2013-2014. Brussels: Fooddrinkeurope.

Freel, M.S. (2003). "Sectoral patterns of small firm innovation, networking and proximity", Research Policy, 32, 5, 751-770.

Freel, M.S. \& Harrison, R.T. (2006). "Innovation and cooperation in the small firm sector: Evidence from 'northern britain'", Regional Studies, 40, 4, 289-305.

Gallant, A. R., Nychka, D. N. (1987). Semi-nonparametric maximum likelihood estimation. Econometrica 55: 363-390.

Garcia Martinez, M., \& Britz, J. (2000). Innovation in the Spanish food \& drink industry. International Food and Agribusiness Management Review, 3, 155-176.

Gemünden, H.G., Ritter, T. \& Heydebreck, P. (1996). "Network configuration and innovation success: An empirical analysis in german high-tech industries", International Journal of Research in Marketing, 13, 5, 449-462.

Gorton, M., Davidova, S., Banse, M., Bailey, A. (2006). The international competitiveness of Hungarian agriculture: Past performance and future projections. Post-Communist Economies, 18 (1): 69-84.

Gronum, S., Verrynne, M.-L. \& Kastelle, T. (2012), "The role of networks in small and medium-sized enterprise innovation and firm performance", Journal of Small Business Management, 50, 2, 257-282.

Harrisson J.S., M.A. Hitt, R.E. Hoskisson and D.R. Ireland, (2001). Resources complementarity in business combinations: extending the logic to organization alliances. Journal of Management 27: 679-90.

Hausman, A. (2005), "Innovativeness among small businesses: Theory and propositions for future research", Industrial Marketing Management, 34, 8, 773-782.

Hitt, M.A., Dacin, T.M., Levitas, E., Arregle, J.-L. \& Borza, A. (2000), "Partner selection in emerging and developed market contexts: Resource-based and organizational learning perspectives", The Academy of Management Journal, 43, 3, 449-467.

Huizingh, Eelko KRE. (2011) "Open innovation: State of the art and future perspectives." Technovation 31.1 (2011): 2-9.

Huggins, R. (2000), "The success and failure of policy-implanted inter-firm network initiatives: Motivations, processes and structure", Entrepreneurship and Regional Development, 12, 2, 111-135.

Huggins, R. \& Johnston, A. (2009), "Knowledge networks in an uncompetitive region: SME innovation and growth", Growth and Change, 40, 2, 227-259.

Hurmelinna-Laukkanen, Olander, H., Blomqvist, K. \& Panfilii, V. (2012), "Orchestrating R\&D networks: Absorptive capavity, network stability, and innovation appropriability", European Management Journal, 30, 552-563.

Ireland, D.R., Hitt, M.A. \& Vaidyanath, D. (2002), "Alliance management as a source of competitive advantage", Journal of Management, 28, 3, 413-446.

Kostopoulis, K., Papalexandris, A., Papachroni, M. Ioannou, G. (2011). Absorptive capacity, innovation and financial performance, Journal of Business Research 64: 1335-1343.

Köhler, C., Sofka, W. \& Grimpe, C. (2012), "Selective search, sectoral patterns, and the impact on product innovation performance", Research Policy, 41, 1344-1356. 
K.G. Grunert, L.F. Jeppesen, K.R. Jespersen, A.M. Sonne, K. Hansen, T. Trondsen (2005), Market orientation of value chains: a conceptual framework based on four case studies from the food industry, European Journal of Marketing, 39 (2005), pp. 428-455

Knudsen, M.P. (2007), "The relative importance of interfirm relationships and knowledge transfer for new product development success", Journal of Product Innovation Management, 24, 2, 117- 138.

Klerkx, L. \& Leeuwis, C. (2008), "Matching demand and supply in the agricultural knowledge infrastructure: Experiences with innovation intermediaries", Food Policy, 33, 3, 260-276.

Lane, P.J., Salk, J.E. \& Lyles, M.A. (2001), "Absorptive capacity, learning, and performance in international joint ventures", Strategic Management Journal, 22, 12, 1139-1161.

Lefebvre, V. 2014. Learning and Innovation in Food SMEs: Network Composition and Management. Doctoral Dissertation, Ghent University

Lefebvre, Virginie Marie, Hans De Steur, and Xavier Gellynck (2015). "External sources for innovation in food SMEs." British Food Journal 117.1 (2015): 412-430.

Lichtenthaler, Ulrich. "Open innovation: Past research, current debates, and future directions." The Academy of Management Perspectives 25.1 (2011): 75-93.

Lundvall, B.A. (1995), National systems of innovation: Towards a theory of innovation and interactive learning London.

Menrad, K. (2004), "Innovations in the food industry in Germany", Research Policy, 33, 6-7, 845-878.

Nieto, M. J. Santamar1'a, L. (2010). Technological collaboration: bridging the innovation gap between small and large firms. Journal of Small Business Management 48(1): 44-69.

Nieto, M.J. \& Santamaría, L. (2007), "The importance of diverse collaborative networks for the novelty of product innovation", Technovation, 27, 6-7, 367-377.

Nonaka, I., Toyama, R. \& Konno, N. (2000). "Seci, Ba and leadership: A unified model of dynamic knowledge creation", Long Range Planning, 33, 1, 5-34.

Oltra, M.J. Flor, M. (2003). The Impact of Technological Opportunities and Innovative Capabilities on Firms' Output Innovation. Creativity \& Innovation Management 12 (3), 137-145.

Ozman, M. (2009), "Inter-firm networks and innovation: A survey of literature", Economics of Innovation and New Technology, 18, 1, 39-67.

Pittaway, L., Robertson, M., Munir, K., Denyer, D. \& Neely, A. (2004), "Networking and innovation: A systematic review of the evidence", International Journal of Management Reviews, 5, 3-4, 137-168.

Purcarea, I., Del Mar Benavides Espinosa, M. \& Apetrei, A. (2013), "Innovation and knowledge creation: Perspectives on the SMEs sector", Management Decision, 51, 5, 1096-1107.

Reed, Richard, Susan Storrud-Barnes, and Len Jessup (2012). "How open innovation affects the drivers of competitive advantage: Trading the benefits of IP creation and ownership for free invention." Management Decision 50.1 (2012): 58-73.

Rese, Alexandra, and Daniel Baier (2011). "Success factors for innovation management in networks of small and medium enterprises." R\&D Management 41.2 (2011): 138-155.

Rothwell, R. és Dodgson, M. (1994). Innovation and size of firm", in: M. Dodgson \& R. Rothwell (szerk.) The Handbook of Industrial Innovation, Aldershot, Hants.: Edward Elgar.

Steffen, W. Stephan, J. (2008). The role of human capital and managerial skills in explaining productivity gaps between east and west. Eastern European Economics, . 46 (6): 5-24.

Stewart, M.B. (2004). Semi-nonparametric estimation of extended ordered probit models. Stata Journal, 4 (1): 27-39 
Stock, G.N., Greis, N.P. Fischer, W.A. (2001). Absorptive capacity and new product development. Journal of High Technology Management Research 12 (1), 77-91.

Slowinski, G., \& Sagal, M. W. (2010). Good practices in open innovation. ResearchTechnology Management, 53(5), 38-45.

Teece, D., (1986). Profiting from technological innovation: Implications for integration, collaboration, licensing and public policy", Research Policy 15(6): 285-305.

Teece, D., Pisano, G., Shuen, A. (1997). Dynamic Capabilities and Strategic Management, Strategic Management Journal, Vol. 18, No. 7. pp. 509-533.

Teis Hansen and Lars Winther (2011). Innovation, regional development and relations between high- and low-tech industries European Urban and Regional Studies July 2011 18: 321-339, first published on June 8, 2011 doi:10.1177/0969776411403990

Tether, B. (2002). Who cooperates for innovation, and why. An empirical analysis", Research Policy 31: 947-967.

Tsai, W. (2001), "Knowledge transfer in intraorganizational networks: Effects of networks position and absorptive capacity on business unit innovation and performance", The Academy of Management Journal, 44, 5, 996-1004.

Tomlinson, P.R. \& Fai, F., M. (2013), "The nature of SME co-operation and innovation: A multi-scalar and multi-dimensional analysis", International Journal Production Economics, 141, 1, 316- 326.

Torkelli, M.T., Kock, C.J. Salmi, P.A.S. (2009). The 'Open Innovation' paradigm: A contingency perspective. Journal of Industrial Engineering and Management 2(1): 176207.

Tödtling, F., Lehner, P. \& Kaufmann, A. (2009), "Do different types of innovation rely on specific kinds of knowledge interactions?", Technovation, 29, 1, 59-71.

Zahra, S.A. \& George, G. (2002), "Absorptive capacity: A review, reconceptualization, and extension", Academy of Management Review, 27, 2, 185-203

Van Der Borgh, M., Cloodt, M. \& Romme, G.A.L. (2012), "Value creation by knowledgebased ecosystems: Evidence from a field study", R\&D Management, 42, 2, 150-169.

Vos, J.-P. (2005), "Developing strategic self-descriptions of SMEs", Technovation, 25, 9, 989-999.

Zeng, S.X., Xie, X.M. \& Tam, C.M. (2010), "Relationship between cooperation networks and innovation performance of SMEs", Technovation, 30, 3, 181-194 